\title{
Economic and Legal Aspects for Construction Business to Ensure Environmental Safety by Self-Regulating Organizations: The Case of Russia
}

\author{
Submitted 13/06/20, $1^{\text {st }}$ revision $23 / 07 / 20,2^{\text {nd }}$ revision $28 / 08 / 20$, accepted $30 / 09 / 20$ \\ Yuliya G. Leskova ${ }^{1}$, Irina K. Kuzmina ${ }^{2}$, Tahir E. Rakhmatullin ${ }^{3}$, Natalia V. \\ Dzhagaryan $^{4}$, Denis A. Popyrkin ${ }^{5}$, Vera N. Kolodkina ${ }^{6}$ \\ Abstract:
}

Purpose: The purpose of this study is to develop recommendations for improving the level of environmental safety in construction through self-regulation mechanisms.

Design/Methodology/Approach: To achieve this purpose the authors used the following general and private scientific methods: dialectical, logical, system and complex analysis, comparative legal, formal legal, statistical and legal modeling methods.

Findings: The authors investigate the anthropogenic impact of the construction industry on the environment, justify the increase in the environmental efficiency of the economy through the participation of self-regulating organizations in the regulation of natural resources and environmental relations. The article analyzes the impact of negative factors of various etymologies mainly in the regions of the North-Western Federal district.

Practical Implications: The use of new ways to increase greening in the construction business within the framework of existing self-regulation mechanisms will increase the entrepreneurs ' awareness level to reduce the anthropogenic impact on the environment.

Originality/Value: The conclusions of this study will contribute to improve efficiency in ensuring environmental safety in the construction sector.

Keywords: Ecology, construction business, self-regulation, self-regulating organizations.

JEL Classification Codes: K32, O29.

Paper type: Scientific article.

Acknowledgment: The reported study was funded by RFBR according to the research project № 18-011-00974 "Self-regulating organization as a legal model for the introduction and the development of social entrepreneurship in the construction sector".

\footnotetext{
${ }^{I}$ The Head of the Business, Labour and Corporate Law Department of the Institute of Law and National Security, Russian Academy of National Economy and State Administration of the Russian Federation, Moscow, Russian Federation, leskova-yg@ ranepa.ru;

${ }^{2}$ Associate Professor of the Civil and Business Law Department, Ulyanovsk State University, Ulyanovsk, Russian Federation.

${ }^{3}$ The Lecturer-researcher of the Civil and Business Law Department, Ulyanovsk State University, Ulyanovsk, Russian Federation.

${ }^{4}$ Associate Professor of the Municipal Law and Environmental Legislation Department of Southern Federal University, Rostov-on-Don, Russian Federation.

${ }^{5}$ The lawyer of the company with limited liability "Ciardis laboratories LTD" (China, Hong Kong) in Moscow, Moscow, Russian Federation.

${ }^{6}$ Associate Professor of the Civil Law Department, Russian State University of justice (Rostov-on-Don branch), Rostov-on-Don, Russian Federation.
} 


\section{Introduction}

Every year, the number of negative impacts on the environment from human activity is increasing. Despite the great efforts of ecologists all over the world to develop recommendations aimed at reducing the anthropogenic impact, environmental problems are becoming more and more widespread.

The latest research published in the first quarter of 2020, showing a positive trend in reducing air pollution for two main indicators, caused by the numerous organizations' activity suspension due to the coronavirus pandemic, notes at the same time a continuing trend towards warming the global climate.

The authors of the study predict that if the global temperature increases by $4^{\circ} \mathrm{C}$ by 2100 under the "high emissions" scenario, at least $15 \%$ of biotic communities around the world will suffer a catastrophic negative impact and loss a biodiversity.

More than one of five their constituent species will cross the threshold beyond their niche limit within one decade. This result can cause irreversible damage to the functioning of the planet's ecosystem (Trisos, Merow, and Pigot, 2020).

The Russian Federation is the world's fourth largest emitter of carbon dioxide (after China, the United States, and India), accounting for about 5 percent. Almost half of global $\mathrm{CO} 2$ emissions occurs in the electricity sector, with manufacturing industry and construction accounting for about 20 percent (Ritchie and Roser, 2020).

Climate change is a large-scale environmental problem, but it is not the only one that we have to face in the construction sector in Russia. Thus, experts highlight the anthropogenic impact of the construction and near-construction sectors, which is manifested in the mass felling of forests, displacement of animals, fish and birds from their permanent habitats, the destruction of established ecosystems, the pollution of reservoirs and soils, the violation of the construction waste utilization technology (Moiseev, 2017), as well as significant changes in the quality of land plots and soils, the irrational use of natural resources in construction, negative impact and destruction of environmental components, nature pollution during the operation of construction facilities (Kotina, 2016).

One of the criteria for the state of the environmental protection is environmental safety. Article 1 of the Federal law "On environmental protection" (2002) reveals what exactly is included in the concept of environmental safety. In particular, this is the state of protection of the natural environment and vital human interests from possible negative impacts of economic and other activities, natural and man-made emergencies, and their consequences. The violation of environmental safety entails the risk of natural objects destruction, environmental pollution and, as a result, a threat to vital human interests. In this regard, it is particularly important for us to comply with the requirements of environmental safety in construction and repair 
work, since even slight deviation from the construction rules, requirements of regulatory legal acts can lead to fatal consequences not only for human life and health, but also for the environment.

\section{Theoretical Foundation and Methodology}

In science, issues of interaction between human activity in construction and the environment, their impact on each other in terms of ensuring environmental safety, preserving and replenishing natural resources through state and public regulation and control are discussed from time to time. Thus, Sheinin (1989) studied the landscapes transformation as a result of construction activity in the USSR. Romanova (2012) in her monograph investigated the legal regulation of construction and modernization of energy facilities, Boltanova (2015) solved in her work the problems of the legislation harmonization in the field of ecology and urban development, regulating land development.

In Russia, large-scale scientific conferences are held on environmental safety issues, which also raise issues of creating and modernizing mechanisms for neutralizing the anthropogenic impact of construction processes on the environment ${ }^{7}$.

The methodological basis of the research consists of general methods such as dialectical, logical, system and complex analysis method, as well as private scientific methods such as comparative legal, formal legal, statistical and legal modeling methods.

The use of these methods makes it possible to identify significant problems of ensuring environmental safety in the construction sector, to find connections between the general and the private, to analyze legal norms, to compare and summarize facts, to determine trends in legal regulation of the analyzed relations and to draw conclusions on the research topic.

\section{Results and Discussion}

Significant changes have occurred in the construction industry in 2018-2019, when the new mechanism of housing construction financing was approved. In the medium term, this will become a determining factor for the industry, entail largescale capital costs and have a great impact on its formation. Due to the fact that

\footnotetext{
${ }^{7}$ The latest major conferences are: The III North-Western Interregional Public Environmental conference (2018), The International scientific and technical conference " Environmental safety in construction and urban economy» (ESCUE-2019), International scientific conference «Energy, Environmental and Construction Engineering» (EECE-2019).
} 
construction directly affects the environment, its rapid development negatively affects the environment as a whole.

According to Article 72 of the Constitution of the Russian Federation, issues of environmental safety, environmental protection and other issues related to nature management are under the joint jurisdiction of the Russian Federation and its subjects, so each region develops its own environmental standards based on territorial and economic needs. For example, in the Republic of Komi, there are more than twenty regional normative acts regulating relations in the field of natural resources management (KOMI, 2020).

Thus, organizations, in addition to direct construction activity, need to independently account for and analyze sometimes not corresponding provisions from various areas of management.

The main provisions of the Federal law "On environmental protection" (2002) concerning issues of ensuring environmental safety are specified in special industry legislation of the Russian Federation. The Town-planning code of the Russian Federation (hereinafter TPC) can be called among these sources, since it is during the urban development objects are created, the operation of these objects may cause different negative impact on the environment and lead to the violation of the environment and vital interests of a person, and, as a result, to the significant violation of environmental rights of citizens. With this, in 2014 the concept of an object that has a negative impact on the environment as a capital construction object was introduced into the conceptual framework of the Federal law "On environmental protection". This established a direct legal link between environmental and urban development relations. In this regard, it is necessary to note their two-fold connection.

So, on the one hand, the unjustified building of a capital construction object can harm the environment or some of its components, cause the ecosystem degradation, which, in turn, will violate the constitutional right of a person to a favorable environment. On the other hand, it is necessary during urban development activity to consider the geographical conditions of a particular locality, whether there are potentially harmful natural objects (i.e. objects which can entail any adverse incident in the form of, for example, the formation of landslides, mudflows, etc.). In connection with this the urban development activity should be based on natural factors of the territories, and the possible negative impact of urban development results on the environment.

It should be noted that all the stages of regulation and implementation of urban development activity should contain legal mechanisms for taking into account these environmental factors, which, in essence, are preventive mechanisms for protecting the environmental rights of the people, the state and society. 
Environmental requirements in construction must be strictly observed during the development of the construction organization project, as well as mandatory compliance with environmental requirements should be noted in the work project. The section of environmental measures in the project documentation is developed at the final stages of designing after the development of technology, the master plan, heating and ventilation systems, water supply, sewerage and gasification. Only a specialist ecologist can properly assess the natural resource costs and restrictions regulated by the legislation of a region in order to provide the organization with an exhaustive list of environmental documentation necessary for the project, as well as explain the sequence of necessary environmental and natural restoration measures.

Despite this, in practice, entrepreneurs often do not properly understand the consequences of taken actions on natural processes that are not preventable. For example, the decision of the arbitration court of Saint Petersburg and Leningrad Region from November 28, 2019 in case No. A56-74432/2019 satisfied the claim of the territorial state authority to the joint-stock company for recovery of damage caused to water biological resources during construction work. The defendant claimed that all the work was carried out in strict accordance with the legislation in the field of nature management and environmental protection, and all the necessary permits and approvals were received. During the trial, it was established that any work carried out in the water area leads to a deterioration of the conditions for the existence of hydrobionts, which disrupts the normal flow of production processes in reservoirs. It is impossible to prevent harmful effects of the work on aquatic organisms.

In this connection, the defendant was obliged to release fish fingerlings as compensation measures in accordance with paragraph 7 of the Regulations on measures for the conservation of aquatic biological resources and their habitat (Decree of the Government of the Russian Federation, 2013). Damage caused to the environment by legal entities is compensated regardless of the intent to cause it.

A construction company as a member of self-regulating organizations (hereinafter SRO) in the construction industry to develop environmental solutions for the project forced to turn to the relevant organization in the field of ecology. The project organization (a member of the SRO) and the self-regulating organization itself is responsible for the quality of all the project documents, including project sections connected with environmental protection. Thus, ecologists are not actually responsible for the quality of their work. It would be fair and logical if the relevant requirements are applied to environmental specialists who prepare environmental sections for the construction business.

According to Article 2 of the Federal law "On self-regulating organizations" (2007), self-regulation refers to independent and initiative activity carried out by business or professional entities and connected with the development and establishment of standards and rules for these activity, as well as monitoring compliance with the 
requirements of these standards and rules. Thus, it is appropriate for ecologists who are members of specialized SRO bodies in the field of construction to monitor the implementation of environmental standards and rules by construction organizations.

In addition, in order to improve the quality of work and the innovative techniques use for nature protection, the personal responsibility of ecologists in construction is justified. Such a legal mechanism applies to specialists organizing engineering work and architectural design and for the construction (article 55.5-1 of Civil Code of the Russian Federation), which from the very beginning of its operation has proved itself as an effective component of increasing the staff qualification of construction organizations - members of SRO. Dautya (2018) is quite right that such subjects, by virtue of their legal status, are endowed with special legal capacity due to the labour relations with a member of the SRO. In this regard, they become subjects of professional responsibility for the quality of work.

Consequently, for the implementation of the conception of effective symbiosis of interdependent components of a system for the safe human life it is necessary to envisage the inclusion of specialists responsible for environmental protection among the subjects of self-regulation in construction. These specialists should be personally responsible for ensuring environmental security. It is necessary to establish certain qualification requirements for them (such as education, experience in the specialty, the frequency of training or an independent assessment of qualification). Selfregulating organizations should not duplicate the powers of the relevant executive authority and establish a formal entry of subjects for obtaining the admission to the market, but, as Yershova (2015) correctly notes, form a comprehensive and protecting the right of entrepreneurs to control all the market sectors. Taking the intermediate position between state authorities and economic entities, the SRO is something like "buffer" in regulating narrow-profile public relations.

The Constitutional Court of the Russian Federation in its ruling No. 461-O-O from February 10, 2009 stated that self-regulating organizations as civil society institutions with public functions is an embodiment of the self-government and autonomy principle in the economic sphere as the manifestation of the constitutional principle of a democratic legal state and the freedom of economic activity guaranteed by the Constitution of the Russian Federation.

In this regard, Leskova (2018) notes that self-regulating organizations with mandatory membership satisfy the public interest public interests, and selfregulating organizations with voluntary participation satisfy the public interest private ones. Voskresenskaya (2016) also emphasizes that the SRO is an organization created to protect the rights and not only of its members, but also interests of an unlimited circle of persons.

Since the development and the use of environmental standards are primarily aimed at protecting the public interest, the specialists who apply these standards at all the 
stages of construction work should operate in accordance with existing selfregulatory mechanisms in the construction industry.

At the intersection of construction activity and ensuring environmental safety, it is necessary to understand that additionally developed standards and rules of selfregulating organizations not contradicting and continuing federal and regional norms, as well as disciplinary measures against unscrupulous members of the SRO, will help to minimize the anthropogenic impact of the construction industry on the environment and the health of generations.

It should be noted that self-regulation in construction is a stable foundation for environmental innovation. In particular, part 1 of Article 55.1 of the Civil Code of the Russian Federation establishes, among other goals, basic goals of SRO builders such as the prevention of harm to the environment, improving the quality of construction activity in the reconstruction and overhaul.

Thus, the national associations of SRO (National associations of builders and National register of prospectors and designers) develop and approve standards for the work in the field of construction. These standards are mandatory for the SRO members. For example, the Council of the Association "National Association of builders" approved 161 standards that apply to all the types of construction work from June 1, 2019 in accordance with changes to the provisions of Civil Code of the Russian Federation and three more standards from January 1, 2020 (according to the official website of the Association "National Association of builders"). The rules for work in these standards are based on the conception of "green" construction ${ }^{8}$. Accordingly, the creation of these standards, which include increased environmental requirements in the field of construction is an additional guarantee of the safety of the building, structures for the environment, this contribute to prevent and minimize possible risks. In addition, the construction activities of SRO using the standards of "green" construction also entail economic benefits, which are manifested at the stage of operation of the building (in the form of reduced energy consumption, water, etc.).

The vast majority of entrepreneurs believe that environmental standards are something secondary, bearing unnecessary excess costs, and until the relevant state bodies check compliance with environmental legislation, company managers look at these standards, to put it mildly, "through their fingers".

Not all the organizations have established departments for environmental safety, an ecologist on staff, and environmental consulting and audit services entails significant

\footnotetext{
${ }^{8}$ We are talking about modern world practice in the construction and operation of buildings, aimed at reducing the level of energy and material resources consumption and reducing the harmful impact of construction on the environment.
} 
economic costs. Moreover, the preparation of environmental documentation is unlicensed. Accordingly, an organization that has applied for environmental consulting services is not protected from the negative consequences caused by unskilled services. Undoubtedly, the organization can use judicial protection, but judicial processes consume a lot of resources (temporary, financial, and human resources), while preventive measures are more effective in stabilizing international economic relations.

At the same time, penalties for the environmental legislation violation are quite high. For example, the implementation of activity without appropriate documentation (documentation with a positive conclusion of state ecological expertise), shall entail imposing a fine on the organization in the amount of one hundred thousand to two hundred fifty thousand rubles (Art. 8.4 of the Administrative Code). It is not only the fear of liability and significant economic losses that are essential, but also the awareness of business in ensuring environmental safety of the construction industry.

There are various certification systems in the world, the most famous international "green" standards in construction are: the BREEAM system (in the UK), the LEED system (in the US), the DGNB system (in Germany). In the Russian Federation, the application of these standards is voluntary. So, in accordance with BREEAM system there are only 176 certified projects in our country (GreenBookLive, 2020), in accordance with LEED system there are 122 certified projects (statistics from the official website of the U.S. Green Building Council). Obviously, such examples are extremely insignificant. Moreover, not all the buildings submitted for certification pass it because they do not meet even the minimum requirements, which proves the weak regulation of business relations in the construction sector through the prism of ensuring environmental sustainability.

\section{Conclusions}

The research makes it possible to identify the need of the construction industry to increase awareness when consuming natural resources, greening construction processes and ensuring environmental protection. The need to introduce a new subject of the self-regulation system with a specific functions is due to the following factors:

1.Providing energy saving and energy efficiency systems, the rational water use will significantly reduce the cost of operating buildings and structures. In relation to construction organizations, interaction with experts in the field of environmental safety at the level proposed in the article will minimize the violation of environmental legislation and the application of administrative, property and disciplinary measures (imposed by a self-regulating organization) to them.

2. Improving the professional level of specialists, increasing competition between them and, as a result, achieving a higher quality of work. 
3. Ensuring proper monitoring of compliance with federal and regional environmental and urban development legislation, standards and rules of selfregulating organizations in the construction sector.

4.Through the formation of an eco-oriented model of construction work in each organization, the greening of the construction sector as a whole will be achieved.

Thus, the mandatory availability of an environmental safety specialist with a special legal status and personal responsibility in a construction organization - a member of the SRO can become a powerful regulator in ensuring environmental safety in the construction sector.

\section{References:}

Boltanova, E.S. 2015. Environmental and legal framework for the regulation of land development by buildings and structures in Russia. D.Sc thesis abstract, Tomsk, 54 .

Court. 2019. The decision of the Arbitration Court of the city of St. Petersburg and the Leningrad Region of November 28, 2019, case No. A56-74432 / 2019.

Dautia, T.V. 2018. Features of the legal status of specialists in the organization of engineering surveys, architectural and construction design, construction. Bulletin of Moscow State Regional University. Series: Law, 2, 49-60.

Decree. 2013. Decree of the Government of the Russian Federation of April 29, 2013 No. 380 "On approval of the Regulation on measures for the conservation of aquatic biological resources and their environment".

Ershova, I.V. 2015. Self-regulation of entrepreneurial and professional activities: unity and differentiation. Moscow, INFRA-M.

GreenBookLive. 2020. Database from an independent third-party certification authority BRE Global. Available at:

https://www.greenbooklive.com/search/buildingsearch.jsp?partid=10023\&subschem eid $=0 \&$ subsubschemeid $=0 \&$ company Name $=\&$ developer $=\&$ productName $=\&$ buildin gRating $=\&$ certNo $=\&$ certBody $=\&$ assessor Auditor $=\&$ countryId $=35 \&$ addressPostcod $\mathrm{e}=\&$ standard $=\&$ notes $=\&$ project $\mathrm{Type}=\& \mathrm{id}=202$

KOMI. 2020. Ministry of Natural Resources and Environmental Protection of the Komi Republic. Available at: http://mpr.rkomi.ru/left/doc/npark/

Kotina, M.Yu. 2016. The concept of "construction" in a broad and narrow sense: the legal aspect. Environmental law, 5, 15-19.

Leskova, Yu.G. 2018. To the question of the features of the legal status of self-regulatory organizations in the field of capital construction, design and engineering surveys. Laws of Russia: experience, analysis, practice, 1, 45-51.

Moiseev, V.V. 2017. Actual environmental problems in Russia. City management: theory and practice, 3 (26), 3-9.

NOSTROY. 2020. National Association of Builders. Available at: https://nostroy.ru/standards-snip/standarty_na_procesy/

Ritchie, H., Roser, M. 2020. $\mathrm{CO}_{2}$ and Greenhouse Gas Emissions. Available at: https://ourworldindata.org/co2-and-other-greenhouse-gas-emissions

Romanova, V.V. 2012. Legal regulation of the construction and modernization of energy facilities. Lawyer: Moscow, 426. 
Yuliya G. Leskova, Irina K. Kuzmina, Tahir E. Rakhmatullin, Natalia V. Dzhagaryan, Denis A. Popyrkin, Vera N. Kolodkina

Sheinin, L.B. 1989. Capital construction and environmental protection. Moscow, Stroyizdat, 184.

TPC. 2020. The Town Planning Code of the Russian Federation, December 29, 2004, No. 190-FZ (as amended on April 24, 2020).

Trisos, C., Merow, C., Pigot, A. 2020. The projected timing of abrupt ecological disruption from climate change. Nature.

USGBC. 2020. U.S. Green Building Council. Available at: https://www.usgbc.org/projects?Country=\%5B $\% 22$ Russia $\% 22 \% 5 \mathrm{D}$

Voskresenskaya, E.V. 2016. Subjects of self-regulation: theoretical and legal aspect. Leningrad Law Journal, 1, 17-23. 